\title{
Phenomenal Conservatism and Skeptical Theism
}

Jonathan D. Matheson

\section{Introduction}

Recently there has been a good deal of interest in the relationship between common sense epistemology and Skeptical Theism. ${ }^{1}$ Much of the debate has focused on Phenomenal Conservatism and any tension that there might be between it and Skeptical Theism. In this paper I further defend the claim that there is no tension between Phenomenal Conservatism and Skeptical Theism. I show the compatibility of these two views by coupling them with an account of defeat - one that is friendly to both Phenomenal Conservatism and Skeptical Theism. In addition, I argue that this account of defeat can give the Skeptical Theist what she wants - namely a response to the evidential argument from evil that can leave one of its premises unmotivated. In giving this account I also respond to several objections from Trent Dougherty (2011) and Chris Tucker (this volume) as well as to an additional worry coming from the epistemology of disagreement.

Before moving into the heart of the argument we need to be clear on the players. There is an alleged tension between common sense epistemology and Skeptical Theism. But what is common sense epistemology? And what is Skeptical Theism?

\section{What is Skeptical Theism?}

\footnotetext{
${ }^{1}$ See for instance Dougherty (2008) and (2011), Bergmann (2009) and (forthcoming), Matheson (2011), and Tucker (this volume).
} 
Skeptical Theism has two separable components: a skeptical component and a theistic component. ${ }^{2}$ My focus here will be on the skeptical component of Skeptical Theism - a component of Skeptical Theism that can be endorsed by an atheist or agnostic. The skeptical component of Skeptical Theism focuses on human cognitive limitations as well as the vastness and complexity of reality. ${ }^{3}$ Paul Draper, formulates the Skeptical Theist thesis as the following claim:

ST: Humans are in no position to judge that an omnipotent and omniscient being would be unlikely to have a morally sufficient reason to permit the evils we find in the world. ${ }^{4}$

The Skeptical Theist utilizes this skeptical component of her view in responding to the evidential argument from evil.

The evidential argument from evil roughly goes as follows:

P1. There exist instances of intense suffering which an omnipotent, omniscient being could have prevented without thereby losing some greater good or permitting some evil that is equally bad or worse.

P2. An omnipotent, omniscient, wholly good being would prevent the occurrence of any intense suffering it could, unless it could not do so without thereby losing some greater good or permitting some evil equally bad or worse.

C. There does not exist an omnipotent, omniscient, wholly good being. ${ }^{5}$

\footnotetext{
${ }^{2}$ Here I am following Michael Bergmann.

${ }^{3}$ See Alston (1991): p. 109.

${ }^{4}$ This parallels Paul Drapers formulation of the Skeptical Theist thesis. See Draper (1996), p. 176.

${ }^{5}$ This formulation follows William Rowe's in "The Problem of Evil and Some Varieties of Atheism" American Philosophical Quarterly 16 (1979), 335-341.
} 
According to Skeptical Theism, we should be skeptical about P1, and if we should be skeptical about P1, the argument fails.

P1 is often motivated by way of a certain type of inference - the 'noseeum' inference. ${ }^{6}$ According to the 'noseeum' inference, we cannot find any justifying reasons for some actual evils, so there probably aren't any such justifying reasons for those evils. Skeptical Theists, however, claim that this application of a 'noseeum' inference is no good due to our cognitive limitations as human beings.

Skeptical Theists differ in terms of how they take it that ST blocks this application of a 'noseeum' inference. Strong Skeptical Theism claims that ST is true, and that the mere truth of ST has it we cannot be justified in believing P1 on the basis of a 'noseeum' inference. ${ }^{7}$ The 'noseeum' inference is blocked because we would not see such justifying reasons even if they were there. Weak Skeptical Theism claims that when an individual is justified in believing ST, she cannot be justified in believing P1 on the basis of a 'noseeum' inference. ${ }^{8}$ Here the inference is blocked when we have undefeated good reason to believe that we wouldn't see such justifying reasons even if they were there. Notice that according to Weak Skeptical Theism, the Skeptical Theist's project can succeed even if ST is in fact false, since an individual can be justified in believing a false proposition. At the same time, since not everyone is justified in believing the same things, the truth of Weak Skeptical Theism does have it that no

\footnotetext{
${ }^{6}$ See Rowe (1979).

${ }^{7}$ I called this view 'Justificatory Skeptical Theism' in Matheson (2011).

${ }^{8}$ I called this view 'Normative Defeater Skeptical Theism' in Matheson (2011).
} 
one can be justified in believing P1 (even if ST is true) - it only offers a way of blocking the motivation for P1.

\section{What is Common Sense Epistemology?}

What then is common sense epistemology? I am taking common sense epistemology as the claim that we are prima facie justified in believing that things are the way that they appear. ${ }^{9}$ In what follows, I will take Phenomenal Conservatism as an epistemic principle representative of common sense epistemology, though there may be ways of being a common sense epistemologist apart from endorsing Phenomenal Conservatism. Phenomenal Conservatism is the following claim:

PC: $\quad$ If it seems to $S$ as if $P$, then $S$ thereby has at least prima facie justification for believing that $P .^{10}$

According to PC, when a proposition seems true to an individual, that individual has prima facie justification for believing that proposition. According to PC, seeming states suffice to provide prima facie justification for believing what seems to be the case - it is not a prerequisite that such seeming states are in fact reliable indicators of the world, or even that the subject is justified in believing that they are. PC is thus a form of dogmatism. ${ }^{11}$ According to PC, the prima facie justification one gets from a seeming

\footnotetext{
${ }^{9}$ This follows Dougherty (2008), but is a departure from how Bergmann (forthcoming) understands 'commonsensism'.

${ }^{10}$ For a further explication and defense of Phenomenal Conservatism see Michael Huemer's Skepticism and the Veil of Perception and "Compassionate Phenomenal Conservatism", as well as Chris Tucker's "Why Open-Minded People Should Endorse Dogmatism" and "Phenomenal Conservatism and Evidentialism in Religious Epistemology."

${ }^{11}$ For more on dogmatism see Jim Pryor's "The Skeptic and the Dogmatist".
} 
state does not depend upon anything but the seeming state itself - it does not depend on one's environment, one's background beliefs, etc. This is not to say that these things cannot defeat the justification provided by seeming states, only that no other states need to obtain in order to provide this prima facie justification.

The defender of PC will also want to distinguish the amount of prima facie justification various seeming states provide. After all, not all seeming states are created equal. So, let's take it that the stronger the seeming, the more prima facie justification provided by it. According to PC, the justification provided by seeming states is only prima facie, it can be defeated. However, if that prima facie justification for a proposition is not defeated, then the subject will also be on balance justified in believing that proposition.

An individual's prima facie justification for believing $\mathrm{p}$ can be defeated in various ways. First, a defeating effect can be either partial or full. It will be partial when $\mathrm{p}$ remains on balance justified for the individual, but becomes less on balance justified for her than it was before she acquired the defeater. A defeating effect will be full when $\mathrm{p}$ is rendered on balance unjustified for her. A defeater can also go about its defeating task in one of two ways. Rebutting defeaters defeat one's justification for $p$ by way of supplying evidence against $p$, whereas undercutting defeaters defeat one's justification for $\mathrm{p}$ without providing evidence against $\mathrm{p}$. Undercutting defeaters typically accomplish their task by attacking the connection between some bit of evidence and the target proposition.

\section{The Problem}


The tension between PC and Skeptical Theism emerges from the fact that, according to PC, there are justificatory routes to P1 that are not blocked by the skeptical component of Skeptical Theism. ${ }^{12}$ While the skeptical component of Skeptical Theism has been advanced primarily to block the 'noseeum' inference to P1, PC provides alternative justificatory routes to this premise of the evidential argument from evil. According to PC, P1 can be justified directly (i.e. noninferentially) by it seeming to one that $\mathrm{P} 1$ is true. ${ }^{13}$ So, given PC, the advocate of the evidential argument from evil need not rely on a 'noseeum' inference to motivate P1, she can motivate this premise directly since according to PC, P1 will have prima facie justification for those to whom P1 seems true. Since PC claims that the prima facie justification for believing a proposition on the basis of a seeming state does not require anything in addition to the seeming state itself, an individual can be prima facie justified in believing P1 even if ST is true. According to PC, the mere truth of ST would not prevent an individual from being prima facie justified in believing P1, since a seeming state suffices to provide prima facie justification for what seems true. If this prima facie justification for P1 is undefeated, those individuals will also be on balance justified in believing P1. Since P1 can seem true to individuals, and plausibly does, it might be thought that the skeptical component of Skeptical Theism is unable to prevent P1 from being motivated once PC makes these additional motivational routes available. If so, then Skeptical Theism is rendered ineffective by PC.

\footnotetext{
${ }^{12}$ See Dougherty (2008) and Tucker (this volume) for more on this point.

${ }^{13}$ In addition, according to PC, an individual can be justified in believing P1 by having a particular evil seem gratuitous, and then inferring P1 from this fact. I take it that in these latter cases P1 also seems true to that individual, and so my focus here will be on cases where P1 is directly justified.
} 


\section{The Compatibility Claim Defended}

It should be clear that Strong Skeptical Theism conflicts with PC. Even if ST is true, PC has it that individuals can be directly justified in believing P1. According to Strong Skeptical Theism, the truth of ST prevents P1 from being justified, yet according to PC, P1 can be justified even if ST is true. Strong Skeptical Theism and PC are indeed incompatible - If PC is true, the mere truth of ST cannot prevent an individual from being justified in believing P1.

Weak Skeptical Theism, however, faces no such tension with PC. According to Weak Skeptical Theism, the motivation for P1 is blocked when one is justified in believing ST. While PC allows that an individual can be prima facie justified in believing $\mathrm{P} 1$, if that individual is also on balance justified in believing ST, her justification for believing P1 will be fully defeated. So, Weak Skeptical Theism provides the resources to prevent P1 from being directly justified (in addition to blocking the 'noseeum' inference to P1). This isn't to say that according to Weak Skeptical Theism P1 couldn't be directly justified for an individual. Given PC it can. The claim here is that when an individual is on balance justified in believing ST, any prima facie justification that she has for P1 (whether direct or indirect) will be fully defeated - that being on balance justified in believing ST prevents one from being justified in believing P1, and thus provides an escape from the evidential argument from evil.

Consider the following analogy. Suppose that you are considering whether Smith is guilty of a crime. You know that there is a great deal of evidence relevant to this matter and 
that the evidence is complicated, although at first you aren't aware of what any of the evidence is. I then tell you a few of the relevant items of evidence. I make it clear to you that you have no reason to believe that the evidence I have told you about is either complete or representative of the total evidence relating to Smith and this crime. Suppose that on your evidence it is just as likely that the items of evidence you are aware of regarding Smith's guilt are unrepresentative of the total evidence regarding Smith's guilt as it is that they are representative. I then ask you, "Does the total evidence, which I have partially described to you, support that Smith is guilty?" Suppose that upon consideration it strongly seems to you that the total body of evidence does support that Smith is guilty of the crime. Perhaps this is because certain other things seem true to you about what else is in the total evidence, even despite my disclaimers and cautions. Given PC, the mere fact that it seems to you that the total evidence supports Smith's guilt gives you prima facie justification for believing that the total evidence supports Smith's guilt. Further this justification is direct and non-inferential. Are you also on balance justified in believing that the total evidence supports that Smith is guilty? No. At least not if you are on balance justified in believing the following analogue to ST:

SK: $\quad$ You are in no position to judge how likely it is that there are countervailing evidential considerations in the total body of evidence.

Being on balance justified in believing SK would block a 'noseeum' inference from what you are aware of in the evidence to what the total body of evidence is like. Further, being on balance justified in believing SK would fully defeat any prima facie justification enjoyed by your belief that the total evidence supports Smith's guilt on the basis of it seeming to you that it does. After all, you have (undefeated) reason to doubt that your seeming that the total evidence 
supports Smith's guilt is indicative of reality. Given that you are on balance justified in believing that you are in no position to judge such matters, the connection between your seeming state and the proposition that the total evidence supports Smith's guilt has been completely undermined. Since you are on balance justified in believing SK, you cannot rationally rely on how things appear to you regarding the total body of evidence. According to PC, you don't need reasons to trust your seemings in order for them to provide you with prima facie justification for what seems true. Nevertheless, if you are on balance justified in believing SK, you have reasons to doubt your seeming. In such a situation, even your direct justification for believing that Smith is guilty has been defeated - you have undefeated reason to suspend judgment about the accuracy of your seeming state. ${ }^{14}$

So, the information about our cognitive limitations as well as the vastness and complexity of reality that Weak Skeptical Theists utilize to block the 'noseeum' inference to P1 can also prevent P1 from being on balance justified directly (i.e. via a seeming state). When you are on balance justified in believing that you are in no position to judge what the total body of evidence supports, this fully defeats any prima facie justification you have for believing that it supports Smith's guilt. Similarly, when you are on balance justified in believing that you are in no position to judge that an evil is gratuitous, this fully defeats any prima facie justification you

\footnotetext{
${ }^{14}$ What I have said above isn't quite right. After all, one of the bits of evidence of which you are aware in the total body of evidence may itself entail that Smith is guilty. In that case, even if you are unaware of what else is in this total body of evidence and how all the relations between the bits of evidence work, you will have great reason to believe that the total body of evidence supports Smith's guilt. Of course, if you were aware of some such entailment, you would not be justified in believing SK either. Applied to Skeptical Theism, we can ignore such a wrinkle since we can acknowledge that none of the evils that we are aware of entails that God does not exist. We should all admit that it is at least possible that there is always a justifying reason (however unlikely). The evidential argument from evil simply asserts that it is unreasonable to believe that there is in fact always such a justification.
} 
have for believing that it is. So, the skeptical component of Skeptical Theism extends beyond blocking the 'noseeum' inference - it also can defeat direct justification for believing P1.

\section{Dougherty's Challenge (part 1)}

While we have seen good reason to believe that there is no tension between PC and Weak Skeptical Theism, not everyone is on board. It has been alleged that there is a tension between PC and Skeptical Theism since it powerfully and persistently seems to many that P1 is the case. ${ }^{15}$ Coupled with PC, this empirical claim has it that many are very strongly prima facie justified in believing P1. Since the Skeptical Theist's response to the evidential argument from evil was to block the motivation for P1, the Skeptical Theist must have a story about how this prima facie justification can be defeated. The tension is thought to come from the fact that the power and persistence of the seeming that $\mathrm{P} 1$ is the case has it that this prima facie justification for P1 will not be defeated by the skeptical component of Skeptical Theism. It is alleged that the seeming that P1 is the case is stronger than the seeming that ST is the case, and thus given PC, has more prima facie justification going for it than does ST. ${ }^{16}$

Here the differences between rebutting and undercutting defeaters are crucial. For a rebutting defeater to be a full defeater, it must provide as much support against $\mathrm{p}$ as the

\footnotetext{
${ }^{15}$ See Dougherty (2008).

${ }^{16}$ What is ultimately at issue is whether ST can defeat one's justification for P1, when one is less justified in believing ST than one is in believing P1. For ease of discussion, I will take it that the justification one has for believing both P1 and ST comes by way of seeming states.
} 
original evidence gave for $\mathrm{p.}^{17}$ So, if ST acted as a rebutting defeater there would be a problem here for the Weak Skeptical Theist. However, an undercutting defeater does not need to be as justified as the proposition whose justificatory effect it is defeating in order for it to be a full defeater. An undercutting defeater will be partial when it doesn't make it the case that one is either on balance justified in disbelieving or suspending judgment toward the target proposition. So, one obtains a partial defeater when one is on balance justified in believing that there is an epistemic support relation between one's evidence and the target proposition, though one has been given some reason to believe that this relation is less strong than had been supposed. For instance, one might receive a report that one's vision is reliable, though less reliable than was on balance justified in believing that it was.

However, an undercutting defeater will be full whenever one is on balance justified in believing that the epistemic support relation between one's evidence and the target proposition is lacking altogether or when one is on balance justified in suspending judgment regarding the claim that one's evidence supports the target proposition. ${ }^{18}$ In Matheson (2011), I gave the following case to motivate this claim:

\footnotetext{
${ }^{17}$ At least this is true if one is on balance justified in believing every proposition which is on balance supported by one's evidence. I will be assuming that this is the case. If one is only on balance justified in believing a proposition that is significantly supported by one's evidence, or supported to degree 0.6 or higher, etc., then a rebutting defeater could be full even if it did not provide as much support from not-p as the original evidence gave for $p$. It could do so by knocking down the individual's on balance justification for believing be to a degree above 0.5 but lower than the threshold for justifiably believing that $p$.

${ }^{18}$ Cases of peer disagreement give us good reason to accept that justified suspension of judgment toward the claim that one's evidence supports $p$ is a full undercutting defeater for one's justification for $p$. In cases of peer disagreement one discovers that someone in an equally good epistemic position with respect to $p$ (equally good evidence, equally intelligent, equally intellectually virtuous, etc.) has adopted a competitor doxastic attitude toward p. Given this discovery, it is plausible that the parties to the disagreement should suspend judgment
} 
[S] uppose that it seems to Smith that the table in front of him is red. According to $\mathrm{PC}$, this provides Smith with prima facie justification for believing that the table in front of him is red. Suppose further that Smith has a memorial seeming that he put on red tinted glasses that make everything look red. On its own, this seeming is not evidence for or against the proposition that the table that Smith is looking is red. However, this bit of evidence does give Smith a normative defeater that fully undercuts the support that Smith enjoyed for the proposition that the table in front of him is red on the basis of its seeming red. Upon having this memorial seeming Smith is no longer justified in believing that the table in front of him is red (at least not on the basis of it seeming red).

We can summarize this story as follows:

S1: it seeming to Smith that the table is red.

S2: it seeming to Smith that he is wearing red tinted glasses

C1: the table is red.

S2 gives Smith prima facie justification for believing that he is wearing red tinted glasses and this gives Smith an undercutting defeater for the support that S1 gave to C1 for Smith. Assuming that the justification Smith has for believing the content of S2 is not itself defeated, and the only justification Smith had for believing C1 came from S1, Smith is no longer justified in believing $\mathrm{C} 1 .^{19}$

The moral from the story is that S1 might well be a more powerful seeming state than S2. And S1 may persist even after Smith has the seeming state S2. Nevertheless, in virtue of having S2, and by not having the prima facie justification provided by it (S2) defeated, Smith is no longer on balance justified in believing C1. Applying the analogy to Skeptical Theism we can consider the following:

S1': it seeming to $S$ that there are morally unjustified evils in the world.

regarding which doxastic attitude their shared evidence supports. If so, it seems that both parties should also suspend judgment regarding the disputed proposition p. For a more thorough defense of this claim see Matheson (2009). See also Bergmann (2005).

${ }^{19}$ Matheson (2011). 
$\mathrm{S2}^{\prime}$ : it seeming to $\mathrm{S}$ that ST is true.

C1': there are morally unjustified evils in the world.

Since ST operates as undercutting defeaters for any direct justification for $\mathrm{P} 1$, it can be a full undercutting defeater for one's justification for P1 even when P1 more strongly seems true to you than ST does, and even when P1 continues to seem true even after you consider ST (which seems true to you). What this shows is that there is no tension between PC and Weak Skeptical Theism, even when P1 seems true. One can coherently maintain both PC and Weak Skeptical Theism. Further, the Weak Skeptical Theist can affirm PC while still claiming that P1 of the evidential argument from evil is unmotivated. For individuals to whom ST seems true, and the prima facie justification provided by these seeming states is undefeated, any justification for P1 (whether direct or by way of a 'noseeum' inference) will be fully undercut or blocked. Coupled with this account of defeat, the apparent tension between PC and Weak Skeptical Theism dissolves.

\section{Tucker's Challenge}

Chris Tucker (this volume) has recently challenged the claim that the skeptical component of Skeptical Theism can or will block direct (or non-inferential) justification for P1. Tucker provides the following example to motivate the claim that the skeptical component of Skeptical Theism is so limited. He asks us to suppose that a mother is looking for her baby. She quickly scans the house and doesn't see the baby. She recognizes that she has failed to look in numerous places and that she should suspend judgment as to whether the places she looked are representative of the places the baby could be in the house. Nevertheless, as she realizes this she looks out the window and sees the baby chasing a dog. Tucker's claim is that despite 
the fact that she is justified in withholding judgment regarding the representativeness of her sample, she is nonetheless (directly) justified in believing that the baby is not in the house. So, being justified in suspending judgment regarding the representativeness of her sample did not defeat her direct justification for believing that the baby is not in the house. ${ }^{20}$

Tucker's focus is on the skeptical scope of Michael Bergmann's set of Skeptical Theist skeptical theses, and not on ST. According to Bergmann, the Skeptical Theist's skepticism is comprised of the following four theses:

ST1: We have no good reason for thinking that the possible goods we know of are representative of the possible goods there are.

ST2: We have no good reason for thinking that the possible evils we know of are representative of the possible evils there are.

ST3: We have no good reason for thinking that the entailment relations we know of between possible goods and the permission of possible evils are representative of the entailment relations there are between possible goods and the permission of possible evils.

ST4: We have no good reason for thinking that the total moral value or disvalue we perceive in certain complex states of affairs accurately reflects the total moral value or disvalue they really have. ${ }^{21}$

Tucker's focus in on ST1-ST3 in particular since he is not sure how to understand ST4 and Bergmann himself holds that "[ST4] is not needed to make the skeptical theist's point."22

\footnotetext{
${ }^{20}$ Tucker (this volume).

${ }^{21}$ Bergmann, “Common Sense Skeptical Theism," p. 4. It may be helpful to read ST1 - ST4 with 'we should suspend judgment or disbelieve that' in the place of 'we have no good reason for thinking that'.

${ }^{22}$ Bergmann (2009): 379.
} 
It seems that Tucker is correct in claiming that the woman is both justified in suspending judgment regarding the representativeness of her sample as well as (directly) justified in believing that her baby is not in the house. This shows us that a justified suspension of judgment regarding the representativeness of one's sample does not always defeat any direct justification that one might have for believing the conclusion of that inference. ${ }^{23}$

However, we can take that conclusion in one of two ways. It might (as Tucker claims) show us that the skepticism of Skeptical Theism cannot prevent P1 from being motivated, or it might show us that there is more skepticism in the Skeptical Theist's skepticism than is evoked in ST1-ST3. I think it is the latter. The heart of the Skeptical Theist's position is that judgments about whether a given evil is gratuitous are simply beyond our cognitive pay grade. More traditionally this has been defended by way of blocking the 'noseeum' inference to P1, but not all considerations that block this inference fully capture the skepticism of Skeptical Theism. So, the full force of the Skeptical Theist's skepticism is not brought to bear in Tucker's case. While the mother is justifiably skeptical about some things (e.g. the representativeness of her sample), she is not justifiably skeptical about others. For instance, filling out the case in a plausible way, the mother is not justifiably skeptical about her perceptual faculties or her ability

\footnotetext{
${ }^{23}$ That said, it's not clear to me that a justified suspension of judgment concerning the representativeness of some sample cannot ever defeat direct justification for believing the conclusion of such an inference. Suppose that there is a very large mosaic with many tiles, however all of the tiles are initially turned backwards. Suppose then that a small number of tiles are flipped. Not many tiles are flipped, and there is no reason to think that the flipped one's are representative of the whole lot. So, an inference from the flipped tiles to what the whole mosaic looks like appears to be unwarranted. Suppose, however, that it also just appears to you that the mosaic is of a forest. Given PC, this gives you prima facie justification for believing that the mosaic is of a forest. Are you also on balance justified in believing that the mosaic is of a forest given what else you know about the vastness of the mosaic and how few tiles have been flipped?
} 
to discern perceptions of her child in good light. Put different, it is not the case that the mother is justified in believing that she is in no position to judge how likely it is that her child is causing her visual perception. If she was justifiably skeptical about her abilities on this front, then it is clear that she would not be justified in believing that her baby was outside of the house, despite the prima facie justification she has for believing this (coming from her perceptual experience). This prima facie justification would be defeated by her higher-order (justified) skepticism about her abilities to discern the location of her child.

Similarly, the Weak Skeptical Theist maintains that if we are justifiably skeptical about our abilities to judge whether a given evil is gratuitous, then this defeats any direct justification we have for believing that the evil in question is gratuitous. So, either Tucker is wrong about the consequences of Bergmann's skeptical theses, or there is more to the skeptical component of Skeptical Theism than Bergmann maintains. ${ }^{24}$

\section{Dougherty's Challenge (part 2)}

Dougherty claims there are several flaws with my case for the compatibility of PC and Weak Skeptical Theism. He claims that the theory of defeat I deployed is flawed (as is defeat talk in general), and that my account doesn't give the Skeptical Theist what she wants, or at least enough of it. ${ }^{25}$

\footnotetext{
${ }^{24}$ These considerations seem to be what Bergmann hopes to capture with ST4. So, while my task here is not to defend Bergmann's conception of the skeptical component of skeptical theism, I also am not convinced that there is a problem with it.

${ }^{25}$ In his reply to my (2011), Dougherty (2011) moves from PC to RC.
} 
First, Dougherty finds my account of defeat implausible and claims that all talk of defeat is utterly misguided. Motivating this conclusion is Dougherty's claim that "if there is defeat, then there is something that is defeated." ${ }^{26}$ Since Dougherty finds no viable candidate for something that has been defeated when one gains a defeater, he concludes that defeat talk is misguided and we should opt for simply talking about the probability of a proposition given a total body of evidence.

Here Dougherty is mistaken in taking the meaning of the technical term 'defeat' to be too much like the folk sense of 'defeat'. It is no challenge to calling a shot in tennis 'a winner', to note that the shot is not a competitor and winners must be competitors. Dougherty is right that when a body of evidence E supports a proposition p, E will always support p. Adding a defeater to $E$ will not destroy this timeless relation between $E$ and $p$. But when one starts with $E$ as a total body of evidence, and adds a defeater for $E^{\prime} s$ justification for $p$ to $E$, this new total body of evidence, $E^{*}$, does not support $\mathrm{p}$ at least as much as $\mathrm{E}$ did (and still does). Defeat language simply reflects this change - a change in what is on balance justified by one's total body of evidence (or to what degree it is on balance justified). It is true that this has only changed by changing what one's total body of evidence is, but this is a noteworthy kind of change - one we note with defeat talk.

$\mathrm{RC}$ : If it seems to $\mathrm{S}$ that $\mathrm{p}$, then $\mathrm{S}$ thereby has a pro tanto reason to believe $\mathrm{p}$.

Dougherty seems to think that the move to RC is important since it makes explicit that seeming states provide reasons (not just prima facie justification). The motivation is that reasons stick around even when the justification they provide doesn't (at least in some sense). As I am understanding PC, it entails RC (the prima facie justification provided by the seeming state is provided in virtue of the reason the seeming state provides), so I will maintain my focus on PC.

${ }^{26}$ Dougherty (2011) p.4. 
Further, the account of defeat on offer is one that is already utilized by defenders of PC.

As such, it is fair game to deploy it in showing the compatibility of PC and Skeptical Theism. For example, Michael Huemer response to external world skepticism embraces this account of defeat. According to Huemer, the external world skeptic fails to render our beliefs about the external world unjustified since she fails to provide us with any (undefeated) positive reason to think that her skeptical hypothesis is true or that we are in fact mistaken. The external world skeptic offers only the mere possible truth of her skeptical hypotheses in an attempt to demonstrate that we lack knowledge about the external world. Huemer explicitly notes that were the external world skeptic to produce (undefeated) evidence that we are radically deceived brains-in-vats (or that some other skeptical hypothesis were true), then our prima facie justification for our external world beliefs would be fully undercut. ${ }^{27}$ Here Huemer is not requiring that the skeptic provide reasons for her skeptical hypothesis that are as good as the reasons that her hypothesis would undercut. Simply being on balance justified in believing her hypothesis is true would fully undercut out external world beliefs. Fortunately, the skeptic has failed to produce such reasons. ${ }^{28}$

\footnotetext{
${ }^{27}$ See Huemer, Skepticism and the Veil of Perception p. 183.

${ }^{28}$ This response may sound anti-Moorean. It is not. A Moorean response to skepticism needn't (and shouldn't) claim that first-order evidence (i.e. here's one hand) defeats higher-order evidence about the quality of that firstorder evidence. The skeptic makes evidence the possibility of skeptical hypotheses, but the mere possibility of these hypotheses is not higher-order evidence that the relevant first-order evidence does not justify the belief that I have hands. The skeptic may take it that her concerns are a higher-order defeater, but the skeptic is simply mistaken on this point. Were the skeptic to produce evidence which made $\mathrm{S}$ on balance justified in believing that $\mathrm{S}$ 's perceptual experiences were not indicative of reality, then $\mathrm{S}$ would not be able to appeal to such first-order evidence (i.e. here is a hand) to defeat the skeptic's defeater. So, the response on offer here is wholly compatible with a Moorean response to skepticism.
} 
Since Huemer utilizes such a conception of defeat in applying PC as a response to external world skepticism it is legitimate to utilize this account of defeat (and defeat talk in general) in showing that PC and Skeptical Theism are not in tension - this account of defeat has been seen by defenders of PC to be an extension of their view.

Dougherty's second complaint is that the red glasses argument from analogy that I have given to show that there is no tension between PC and Skeptical Theism involves fallacious reasoning. Central to this argument was the claim that an undercutting defeater can be full even if it is less on balance justified than the proposition whose evidential work it is defeating. For example, D can be a full undercutting defeater for the justification that $E$ provides for $p$, even if $S$ is 0.8 on balance justified in believing $E$ and only 0.7 on balance justified in believing $D$. Dougherty claims that this model is incoherent and that the degrees of justification for both $D$ and $\mathrm{E}$ can make a difference, even if $\mathrm{S}$ is on balanced justified in believing each.

In particular, Dougherty claims that my reasoning involves committing the base-rate fallacy. He gives the following example to motivate his claim:

Suppose a subject $S$ is chosen at random from a population where approximately $10 \%$ steal from work. So it is 9 probable that she doesn't steal. However, [when] she is asked during a lie-detector test which is $80 \%$ accurate whether she steals, it says she's lying when she says she does not steal. We now have evidence undercutting her testimony. I have a reliable source that says she's lying and the proposition that she's lying entails that her testimony is false, so if I was certain of it, l'd have a full, undercutting defeater.

When asked in tests, many respondents think this means we are no longer justified in believing her testimony. However, this is just a fallacy-the base-rate fallacy-and the odds are still better than 2:1 that $S$ is innocent. This illustrates 
that direct evidence is not the only evidence, and that it's total evidence that counts. Epistemic justification must take into account one's total perspective. ${ }^{29}$ While Dougherty's case does involve fallacious reasoning, he has misunderstood the central thrust of my argument in two critical ways. First, it is important to note that as Dougherty is understanding a lie-detector, the lie-detector can give positive reasons for thinking that the subject's testimony is false, not simply reasons which undermine any evidence that the subject's testimony is true. As such, the type of defeat relevant to Dougherty's case is rebutting defeat and not undercutting defeat (or at least not purely undercutting defeat). Since my response focused on how undercutting defeaters worked and these two types of defeaters operate differently, this is a critical difference.

Second, in Dougherty's case the subject has other independent evidence which both supports the claim that the subject does not steal and has not been undercut by any information given by the lie-detector test. So, even if the lie detector evidence fully undercuts the testimony, we are still left with other evidence regarding the subject which has not been undercut by anything that the lie detector has revealed. Even if we eschew all defeat talk, we have learned nothing that would undercut the original evidence that the subject doesn't steal (the evidence about theft in the general population). As Dougherty is understanding a lie detector, the lie detector presents a partial defeater (by way of rebutting) the original population data (since we have gained reason to think that she does steal), yet since we have more reason to trust the original data than the lie detector results (as Dougherty has set up the

\footnotetext{
${ }^{29}$ Dougherty (2011) p.6.
} 
case), this rebutting defeater will not be a full defeater for that original evidence even if it is a full defeater for her testimonial evidence. ${ }^{30}$

So, Dougherty's example does not show that defeat does not work in the way that I claimed, it only shows that some full defeaters need not fully defeat all of an individual's evidence bearing on $\mathrm{p}$. But this we already knew. This is why in the red glasses case it was important that S1 was the only justificatory route to C1 for Smith. If Smith also had testimonial reasons for believing $\mathrm{C} 1$, then the prima facie justification provided by that testimony would not be undercut by $\$ 2$, and Smith would be on balance justified in believing C1.

Undercutting defeaters need not undercut each and every justificatory route to a given proposition. Some undercutting defeaters may fully defeat some justificatory routes, while leaving others unaffected. Recall that undercutting defeaters attack connections between evidence and a proposition, but to attack one connection is not to attack all of them. To show that an undercutting defeater $D$ for the support that $E$ gives $p$ still leaves $S$ on balance justified in believing $p$ does not show that $D$ was not a full undercutting defeater regarding $E^{\prime}$ s support of $\mathrm{p}$. It is consistent with this picture that $\mathrm{S}$ has some $\mathrm{E}$-independent justification for $\mathrm{p}$ which was unaffected by $D$ (or at least no fully undercut by $D$ ). In fact, this is precisely what is going on in Dougherty's lie detector case. So, Dougherty hasn't shown that the account of defeat on offer here fails, he has only shown that full defeaters needn't eliminate all of one's justification

\footnotetext{
${ }^{30}$ I take it that we are to presume that the population data is more than $80 \%$ reliable, and so we have more reason to trust it than we have reason to trust the lie detector test.
} 
for believing a proposition - they only need to fully defeat a justificatory route to that proposition.

At this point it may appear that this response is in conflict with what I claimed earlier in this paper. I earlier argued that the defeaters employed by the Weak Skeptical Theist are particularly wide ranging - covering both inferential and direct justification for P1. I argued that when an individual is on balance justified in believing ST this will fully undercut any justification for believing P1. That said, this consequence followed from the content of ST, what this particular defeater claimed, and not from the nature of undercutting defeaters in general. While it is possible for some undercutting defeaters to be full while leaving open other justificatory routes to $p$, my claim is that this isn't the case with ST and P1. My claim is that when an individual is justified in believing ST, all justificatory routes to P1 will be blocked, but this does not commit me to claiming that all undercutting defeaters will have such a drastic effect. Some undercutting defeaters don't defeat (even partially) some justificatory routes to a given proposition. So, the defense on offer is simply not committed to the consequences Dougherty claims.

But does this account give the Skeptical Theist what she wants? Defeaters can themselves be defeated. So, if an individual was justified in believing that that the type of seemings involved in ST seeming true to her were unreliable, the proposed Skeptical Theistic defeater could itself be defeated for that individual. If that defeater-defeater was itself undefeated and it continued to seem to S that there are morally unjustified evils in the world, then she would be on balance justified in believing P1. How the account on offer plays out will 
depend upon what seeming states individuals have - an empirical matter. This account leaves open the possibility that some individuals are on balance justified in believing P1 on the basis of P1 seeming true. So, this account may not give some Skeptical Theist's all that they want. That said, it does provide an account whereby the direct and indirect motivation for P1 will be successfully blocked in its entirety - the motivation for P1 will be blocked when an individual is on balance justified in believing ST. While Weak Skeptical Theism does not guarantee that no one will ever be justified in believing $\mathrm{P} 1$, it does provide a way out of the evidential argument from evil. While some Skeptical Theist's might want more, having a way to successfully, rationally defend their theistic beliefs from the evidential problem of evil should be enough to make them happy. ${ }^{31}$

One final rejoinder that Dougherty lobbies is that this account of defeat makes it too easy to be on balance justified in believing P1. Dougherty offers the following principles which he thinks all seem true:

PWR: $\quad$ An omniscient and omnipotent being isn't going to be stuck in the position to choose between the holocaust and something (approximately) as bad or worse.

Anti-STa: A loving God would want us to understand, and an all-powerful God could make us understand.

Anti-STb: God's concept of goodness is neither exactly like ours nor shockingly different from ours.

$\sim$ ST: $\quad$ Humans are in a position to judge that an omnipotent and omniscient

\footnotetext{
${ }^{31}$ It also might be thought to give the Skeptical Theist a project - make ST seem true to people. If they succeed in that task, then those individuals would not be justified in believing P1 (at least so long as those defeaters weren't themselves defeated).
} 
being would be unlikely to have a morally sufficient reason to permit the evils we find in the world. ${ }^{32}$

Given PC, if these principles seem true to you, then you have prima facie justification for believing them too. If P1 also seemed true, then there multiple lines of justification for P1 for you (some direct and some indirect, but all rooted in seeming states). These independent lines of support make it more likely in some sense that P1 is on balance justified. However, just as the justification provided by it seeming to you that ST is true can itself be defeated, the justification provided by these seeming states can also be defeated.

These further claims interact with the ST in different ways. In some cases, an undefeated seeming (one that is not fully defeated) that ST is true would fully undercut the justification provided by the principle (like PWR and Anti-STa), since in these cases being on balance justified in believing ST would fully undermine the connection between it seeming that PWR or Anti-STa were true and PWR or Anti-STa being true. This is because ST is a higher-order claim in comparison with PWR and STa. In other cases its seeming that ST is true would be a rebutting defeater for the prima facie justification for the principle provided by its seeming true. This is because the competitor claims are on the same level (neither is a more higherorder claim than the other). In these latter cases, the strengths of the relevant seemings would matter, given how rebutting defeat works. So, even if ST seemed true to S, if it more strongly

\footnotetext{
${ }^{32}$ Dougherty (2011) p. 9-10.
} 
seemed to $S$ that the negation of ST was true, then S would be on balance justified in disbelieving ST and justificatory routes to P1 would again be opened up. ${ }^{33}$

How strong and how prevalent are the various relevant seeming states? I don't know.

The Skeptical Theist will no doubt care, but even if the desired seeming states are not very prevalent, the Skeptical Theist still has an available defense of her own theistic belief - she still has a way out of the evidential argument from evil. So long as ST seems true to her, and the justification provided by this seeming is not defeated for her (i.e. it does not seem to her more strongly that ST is false, or that her seeming that ST is the case is an unreliable seeming state, etc.), then she has no (fully) undefeated reason to believe P1. Further, and more germane to this paper, the Skeptical Theist's Skeptical Theism has not required her to give up on PC, and no one's commitments to PC has given them reason to abandon Skeptical Theism (at least in its entirety) - Weak Skeptical Theism and PC are compatible theses.

\section{The Challenge of Disagreement}

However, at this point one might worry about the justificatory work that its seeming to $\mathrm{S}$ that ST is true can do when S is aware that ST seems false (and is disbelieved) by other equally intelligent, informed, and open-minded people. While ST might seem true to the Skeptical Theist, doesn't her awareness of epistemic peers ${ }^{34}$ who disbelieve ST neutralize the prima facie

\footnotetext{
${ }^{33}$ The story in such a case would parallel Huemer's treatment of the Mueller-Lyer illusion. See Huemer's Skepticism and the Veil of Perception.

${ }^{34}$ Two individuals are epistemic peers when they are in an equally good epistemic position regarding some proposition - they are equally likely to be right about the matter. For more on epistemic peers see Thomas Kelly (2005) "The Epistemic Significance of Disagreement," in T. Gendler and J. Hawthorne, eds., Oxford Studies in Epistemology, vol. 1. Oxford: Oxford University Press.
} 
justification this principle had in virtue of it seeming true to her? Prominent views in the epistemology of disagreement have it that the awareness of such disagreements call for a suspension of judgment regarding the disputed proposition. ${ }^{35}$

However, far from hurting the Skeptical Theist, such a skeptical consequence of these views of disagreement actually enhances her project. If such a view of the epistemic significance of disagreement is correct and skepticism regarding the disputed proposition is a consequence of the view, then the awareness of the relevant sort of disagreements concerning ST have it that all the parties involved in the disagreement should suspend judgment regarding $\mathrm{ST}$ - that this is the uniquely rational response to the disagreement. However, if an individual considers whether to believe ST and justifiably concludes that suspension of judgment is called for regarding this proposition, then she will also have a full undercutting defeater for the justification provided for P1 coming from P1 seeming true. If P1 seems true to $\mathrm{S}$, and S also justifiably concludes that suspending judgment regarding ST is called for, then S is not on balance justified in believing P1 on the basis of it seeming true to S. This is because a justified conclusion that suspension of judgment regarding a higher-order claim is called for fully defeats the justification one has for any relevant lower-order claim. ${ }^{36}$ So, not only do such views regarding the epistemology of disagreement have it that the disagreement regarding ST have

\footnotetext{
${ }^{35}$ See for instance David Christensen (2007) "Epistemology of Disagreement: The Good News," Philosophical Review 116: 187-218, and Richard Feldman (2006) “Reasonable Religious Disagreements." In L. Antony, ed., Philosophers without Gods: Meditations on Atheism and the Secular Life. New York: Oxford University Press.

${ }^{36}$ For a more detailed defense of higher-order defeat and how a justified suspension of judgment regarding a higher-order defeater has full defeating effects, see Bergmann (2005). "Defeaters and Higher-Level Requirements." The Philosophical Quarterly 55: 419-436, Matheson (2009) "Conciliatory Views of Disagreement and Higher-Order Evidence." Episteme: A Journal of Social Philosophy 6(3): 269-279, and Feldman (2005) "Respecting the Evidence." Philosophical Perspectives 19, 95-119.
} 
the result that the Skeptical Theist is not on balance justified in believing P1, they have it that even the atheist defender of the argument who is aware of the relevant sorts of disagreement regarding ST is also unjustified in believing this premise. So, far from hurting the Skeptical Theist, the seeming consequences of taking epistemic significance of the disagreements seriously regarding ST actually advances her cause, at least given the relevant empirical facts of disagreement regarding them. In fact, they might even have it that no one is justified in believing $\mathrm{P} 1$.

\section{Conclusion}

There is no tension between Skeptical Theism and Phenomenal Conservatism. While the resulting account may not give every Skeptical Theist what she wants (i.e. it does leave the possibility of individuals being on balance justified in believing P1), it will give her what she was principally after - a defense of her own theistic beliefs. ${ }^{37}$ On this account, the atheist fails to make theism unreasonable by giving the evidential argument from evil to certain theists - those to whom ST seems true and for whom this justification is not defeated. Further, considerations of the epistemology of disagreement seem to make the Skeptical Theist's project more far reaching. So, while there may be reasons to reject Skeptical Theism and reasons to reject Phenomenal Conservatism, there are no (undefeated) reasons to reject either of these claims on the basis of the other. ${ }^{38}$

\footnotetext{
${ }^{37}$ Further, this appears to be an asset, rather than a detriment. It seems that people can be justified in believing P1. We want an account that allows for this.

${ }^{38}$ Special thanks to Michael Bergmann, Brandon Carey, Ted Poston, Chris Tucker, and Ed Wierenga for helpful comments on this paper.
} 


\section{References}

Alston, W. (1991). "The Inductive Argument from Evil and the Human Cognitive Condition." In The Evidential Argument from Evil, ed. Daniel Howard-Snyder. Bloomington, IN: Indiana University Press, 97-125.

Bergmann, M. (2005). "Defeaters and Higher-Level Requirements." The Philosophical Quarterly 55: 419-436.

Bergmann, M. (2009). "Skeptical Theism and the Problem of Evil," Oxford Handbook to Philosophical Theology, eds. Thomas Flint and Michael Rea (Oxford University Press, 2009), pp. 374-99.

Bergmann, M. (forthcoming). “Commonsense Skeptical Theism," Science, Religion, and Metaphysics: New Essays on the Philosophy of Alvin Plantinga, eds. Kelly Clark and Michael Rea (Oxford University Press), 30 ms. pages.

Christensen, D. (2007) “Epistemology of Disagreement: The Good News," Philosophical Review 116: $187-218$

Dougherty, T. (2008) "Epistemological Considerations Concerning Skeptical Theism." Faith and Philosophy, 25:2, 172-176.

Dougherty, T. (2011) “Further Epistemological Considerations Concerning Skeptical Theism." Faith and Philosophy 28:3.

Draper, P. (1996) “The Skeptical Theist." In The Evidential Argument from Evil, ed. Daniel Howard-Snyder (Bloomington: Indiana University Press).

Feldman, R. (2005) “Respecting the Evidence.” Philosophical Perspectives 19: 95-119.

Feldman, R. (2006) "Reasonable Religious Disagreements." In L. Antony, ed., Philosophers without Gods: Meditations on Atheism and the Secular Life. New York: Oxford University Press.

Huemer, M. (2001) Skepticism and the Veil of Perception. Rowman \& Littlefield.

Huemer, M. (2007) “Compassionate Phenomenal Conservatism." Philosophy \& Phenomenological Research 74: 30-55. 
Kelly, T. (2005) "The Epistemic Significance of Disagreement," in T. Gendler and J. Hawthorne, eds., Oxford Studies in Epistemology, vol. 1. Oxford: Oxford University Press.

Matheson, J. (2009) "Conciliatory Views of Disagreement and Higher-Order Evidence." Episteme: A Journal of Social Philosophy 6(3): 269-279.

Matheson, J. (2011) “Epistemological Considerations Concerning Skeptical Theism: A Response to Dougherty." Faith and Philosophy 28(3): 323-331.

Pryor, J. (2000) "The Skeptic and the Dogmatist." NOÛS 34:4, 517-549.

Rowe, W. (1979) "The Problem of Evil and Some Varieties of Atheism." American Philosophical Quarterly 16 (1979), 335-341.

Tucker, C. (2010) "Why Open-Minded People Should Endorse Dogmatism." Philosophical Perspectives 24: 529-45.

Tucker, C. (2011) "Phenomenal Conservatism and Evidentialism in Religious Epistemology." In VanArragon, Raymond and Kelly James Clark (eds.). Evidence and Religious Belief. Oxford: Oxford University Press, p. 52-73.

Tucker, C. (ms) "Why Skeptical Theism Isn't Skeptical Enough.” 